JOURNAL OF TOURISM, HOSPITALITY AND ENVIRONMENT MANAGEMENT (JTHEM)

wWw.jthem.com

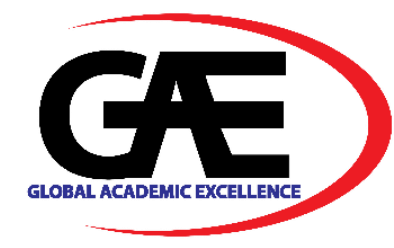

\title{
EXPLORING CULTURAL COMMODITY IN RELIGIOUS TOUR OF MOUNT KAWI
}

\author{
Dwi Sulistyorini ${ }^{1}$, Bani Sudardi ${ }^{2}$, Warto $^{3}$, Mahendra Wijaya ${ }^{4}$ \\ 1 Doctoral Candidate of Cultural Studies Study Program, Sebelas Maret University \\ Email: shoelistr@yahoo.co.id \\ 2 Indonesian Letters Department, Sebelas Maret University \\ Email: banisudardi@yahoo.co.id \\ 3 Department of History, Sebelas Maret University \\ Email: warto_file@yahoo.co.id \\ 4 Sociology Department, Sebelas Maret University \\ Email: mahendrawijaya_uns@yahoo.co.id
}

\section{Article Info:}

\section{Article history:}

Received date: 01.10 .2017

Revised date: 10.10 .2017

Accepted date: 15.08 .2021

Published date: 05.09.2021

\section{To cite this document:}

Sulistyorini, D., Sudardi, B., Warto., \& Wijaya, M. (2021). Exploring Cultural Commodity in Religious Tour of Mount Kawi. Journal of Tourism, Hospitality and Environment Management, 6 (24), 1319.

DOI: $10.35631 /$ JTHEM.624002.

This work is licensed under $\underline{\mathrm{CC} B Y}$ 4.0

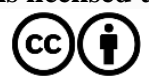

\section{Abstract:}

Mount Kawi is a mountain believed to have supernatural powers. By the existence of Imam Soedjono and Eyang Djugo as historical figures, pilgrims often come to pray in search of blessings. Pilgrims coming to Mount Kawi are not only Javanese but also Chinese. The presence of the ethnic Chinese community influences the cultural distinction in the site. A large number of visitors coming to Mount Kawi brings several shifting elements. To attract the attention of pilgrims, the locals create religious-cultural tourism in Mount Kawi as a compelling attraction. The shift plays a serious impact on the sociocultural dimension. This appealing creativity serves as a commodity for the tourist. Cultural commodity in religious tourism is supported by the interests of the authorities. Thus, the purpose of this study is to reveal the emergence of commodification in Mount Kawi. This study uses a qualitative descriptive method to describe the causes of commodification. The data are obtained from the field, observation, and interviews through informants. The narrative is employed instead of numeric data thus the data are organized, classified, and criticized. Hence, to reveal the cultural commodities in Mount Kawi, the commodification theory and hegemony are applied.

Keywords:

Religious Tourism, Commodities, Culture, Capitalist, Mount Kawi 


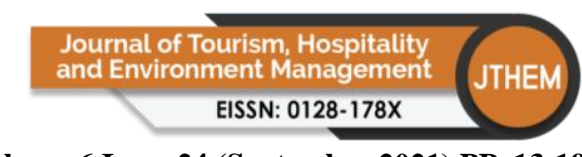

Volume 6 Issue 24 (September 2021) PP. 13-19

\section{Introduction}

DOI 10/35631/JTHEM.624002

The development of tourist destinations in a region is influenced by a variety of factors, one of which is the impact of tourist attractions (Utama, 2016). Because it can entice tourists to visit, attraction is an important factor in moving a tourist destination (Ismayanti, 2010). In essence, tourism is based on the uniqueness, distinctiveness, and authenticity of nature and culture in a given region (Fatimah, 2015). Tourist attractions with a sense of place and authenticity are not only more likely to attract visitors, but also provide a unique experience. Satisfied tourists are more likely to return to the same location for future vacations, as well as to recommend it to friends and relatives (Som and Badarneh, 2011).

Religious tourism, as one of the oldest and most important types of tourism (Smith, 1992; Fleischer, 2000; Siddiq, 2015; Soekadijo, 2000:43), needs to be developed. People are always interested in filling the spiritual aspects of life and the world in which they live, so they judge the meaning of holiness in it (Jaelani et al, 2017). Religious tourism is more popular among tourists than other types of tourism (Widagdo et al, 2017). When compared to other types of tourism, religious tourism has a stable tourism market, high levels of visits, and a continuous number of visitors (Jigang and Yunmei, 1996).

Mountain has a significant hierarchy for the Javanese. Mountain for Javanese is imagined as the throne of supernatural beings, home of the gods, bridging human world and the spirit world (Prastowardoyo \& Anam, 2009, p. 3). Mount Kawi is a mountain that is believed to have supernatural powers. Mount Kawi is located in the district of Malang, East Java. Approximately less than $40 \mathrm{~km}$ from the city of Malang. Mount Kawi is popular due to two prominent propagator's cemeteries of Islam in the region, namely Eyang Djoego dan Imam Soedjono. Both figures are also known as healers, community leaders and role models, as well as loyal soldiers of Pangeran Diponegoro while fighting against Netherlands in 1825-1830 (Prastowardoyo \& Anam, 2009, pp. 27-28). The existence of their cemetery or pesarean invites pilgrimage to come and pray. Having the two figures buried in mount enhances their mythical figures. The crowded mountain is certainly influenced by the charisma of the two, supported by the belief that mountain is a sacred place.

The phenomenon of the swarming visitors has its own appeal. The visitors are diverse, Chinese and non-Chinese, with the purposes of praying, doing ritual, religious activity or just sightseeing. It shows that the visitors have various motivation. The Chinese ornament on the building also plays significant attraction as it brings multicultural atmosphere to the pesarean. The number of visitors increases especially in Suro and Besar (Javanese calendar) because the dates are considered as blessed month.

Legi Friday night, night 1st Shura, Shura March 1st, and the 12th of Muharram mark the born days of Imam Soedjono where many performances are held, such as, puppet show, tahlil or reciting Qoran, hadrah play, javanese art shows, as well as Barongsai performance. In addition, there are offerings and procession for Sengkala or Bathara Kala statue. In this case, indeed, the religious value has been abandoned for the essence of a spiritual ritual. This cultural-religious attraction leads cultural commodity to commodification.

There have been numerous studies on religious tourism of mountain visit, Alamanda et al. (2020) studied business strategy of religious tourism in Mount Haruman, which found several strategies to enhance tourist visits by holding special events, providing navigation, increasing 


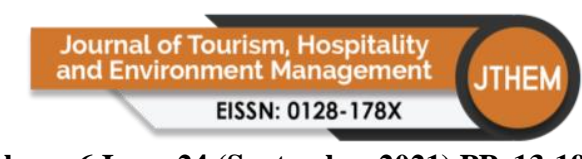

Volume 6 Issue 24 (September 2021) PP. 13-19 DOI 10/35631/JTHEM.624002

promotion, providing and developing various facilities, improving the quality of human resources, establishing cooperation and community ownership, planning and developing tourism, maintaining and repairing infrastructure, as well as improving visitor awareness, Bimantyo \& Islami (2019) describes the concept of developing a tourism market that is representative and connected to Gunung Kawi tourism. Rahmaniah (2016) conducted an ethnographic study to communities living around Gunung Kawi and found some myths that developed in the community related to pilgrimage Gunung Kawi, multiculture messages between Javanese and Chinese culture, syncretism between customs or traditions with religion and for economic system. Sulistyorini et al., (2018) studied the sacred site of Pesarean in Kawi Mountain which has been currently altered into tourism commodity. The study found that the developer, government, and mass media played a significant role in changing the sacred image of today's Pesarean in Kawi Mountain Choe \& Hitchcock (2018) studied the pilgrimage or religious tourism of Mount Bromo which relates the socio-environmental issues of the society. They suggest that the long-term and complex poverty in Indonesia can be eradicated by bringing alive the economic development through tourism.

\section{Method}

This study aims to understand the commodification in Mount Kawi. Therefore, this study used a qualitative research design to understand the phenomena experienced by subjects in a more holistic manner through description in the form of words and language in a natural context (Moleong, 2014, p. 5). Understanding the phenomenon experienced by the subject of the research is to explore and to understand the meaning that comes from the social environment (Cresswell, 2014, p. 4). The efforts of exploration and understanding are to determine the commodification in Mount Kawi. This study is built on a set of assumptions (paradigms) advocacy, where the research is expected to give change to the lives of the participants and the institutions (Creswell, 2007, p. 21). This study focuses on the needs of socially marginalised group, the group that became the victims of the interests of capital in the commodification of folklore in Mount Kawi. In other words, this study is emancipatory research to liberate the marginalized and to correct the injustices caused by the commodification of folklore in Mount Kawi. The approach used in this study is critical ethnography. This approach is consistent with the objectives of this study. Commodification by the capitalist in mount Kawi has an impact on the marginalization of communities and individuals who do not have power but strong interest in cultural products.

Data in this study is the phenomenon of cultural commodities that lead to the commodification of the Mount Kawi and some supporting writings such as History of Mount Mount Kawi, journal articles and media about Mount Kawi. The research data sources are informants, events, and documents. Informants in this study, the caretaker, the Head of Tourism and the Department of Tourism staff Malang, Chairman of the Foundation Ngesti Gondo, visitors and the local community. Events and reality in Mount Kawi are the source of data in accordance with what happened truky in the community when researchers were conducting the research process. The events are the ones related to the commodification of Mount Kawi. Documents used as data for this study derives from books, journals, newspapers, magazines, writing on the Internet, as well as research report related to the research objectives, namely the commodification in Mount Kawi. 


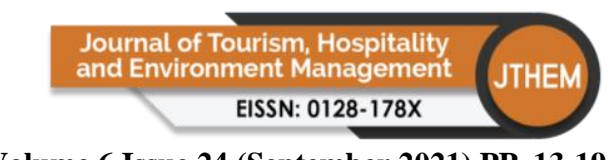

Volume 6 Issue 24 (September 2021) PP. 13-19

\section{Result and Discussion}

DOI 10/35631/JTHEM.624002

\section{Result}

The number of visitors to Mount Kawi is influenced by the notion that the two figures are considered sacred and have supernatural powers. Therefore, the visitors make the tomb as a means to pray that connect people with God. This belief is influenced by Javanese mystics to travel in search for spiritual needs (pilgrimage), such as pilgrimage at the tomb of the ancestors to show their devotion to their predecessor (Endraswara, 2003, p.28). They pray for Imam Soedjono and Eyang Djugo. When praying at the tomb, they are led by a cemetery caretaker enchanting Islamic prayer. Visitors who pray at the tomb of the two figures are not only native but also Chinese.

The Chinese visitors in Mount Kawi came after the arrival of a Chinese named Kie Tan Yam (Pek Yam) for pilgrimage in Mount Kawi in 1931. Mr. Yam found peace in Mount Kawi and decided to settle in Wonosari to serve Eyang Djugo and Imam Soedjono by building a road from pesarean to the bottom dekata stamplat. The existence of Mr Yam in Wonosari is encouraging Chinese people to visit Mount Kawi. Moreover, Ong Hok Liong known as the founder of tobacco companies Bentoel is close to Kie Tan Yam as brothers. When Ong Hok Liong and his wife visited Kie Tan Yam, they met mbah Djuwul and they were given two bentul seeds (a type of mountain plant), then the seeds came as inspiration to make cigarettes with bentul stamp. His efforts eventually succeeded up to now. The news Ong Hok Liong success is spread to everywhere, thus it inspires many Chinese to visit the Mount Kawi.

The number Chinese visitors who came to Mount Kawi similar to the procedures of pilgrimage, it gave the idea to build worshipping place for Chinese. Sunardi, et al (1977, p. 52) explained in 1940 Kie Tan Yam suggested mbah Kasiyo and Mbah Djuwul to build a house of worship for Chinese by the name of Pat Kwa Teng. The ritual is equipped with a pal or fate Ciamsi. The ciamsi bring more crowd for the Chinese to visit Mount. If their prayers are answered, they give souvenirs and some even take off their vow. They perform shadow puppets, salvation, giving the wall clock, wall hangings, lamps, and others. All gifts are accompanied by the writings of the Chinese letter. Consequently, pesarean space is decorated distinctively with Chinese touch. Besides the temple, the mosque also stands as a place of worship of Muslims. The Islam-Chinese mix brings complexity to Mount Kawi. Multiculturalism appears as the cultural diversity and tolerance could go hand in hand. Pagoda Building, ciamsi, and the mosque are the creative practice of the respective creator. This is in line with Willis in forming a common cultural practice based creative consumption (Willis in Barker, 2004, p. 44). The establishment of the building as a place of religious activity certainly adds the cultural creativity in the ritual performed by the visitors in Mount Kawi.

Cultural diversity and religious tolerance in Mount Kawi are characteristics of religious tourism in Mount Kawi. Mount Kawi as a place of religious tourism invites the attention of government to implement entry fees, parking lot, admission ticket, and tour guide services. In addition, the foundation Ngesti Gondo also has authority to regulate for safety services, puppets show, as well as visitors to pray at the tomb. With the role of government and private (foundations Ngesti Gondo) and community support, mount Kawi becomes increasingly well-known, and attracts more attention for tourists and pilgrims. 


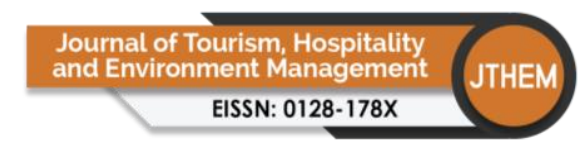

Volume 6 Issue 24 (September 2021) PP. 13-19 DOI 10/35631/JTHEM.624002

\section{Discussion}

Mount Kawi as cultural commodity is supported by three elements, namely the government, the private sector (foundations Ngesti Gondo), and the community. In this case, the government's role is managing the access in Mount Kawi. One that has been done is to build the road leading to the tourist area. Construction of roads gives access to the pesarean area Eyang Djoego and Imam Soedjono. In addition, the government also provides parking tickets, retribution and tax for the sellers in the cemetery. The existence of the tourist area is used as a commodity for the rulers's interest. It raises the form of commodification. The emergence commodification is through capitalism. This capitalism can be said as hunger for money, so that the idea of materialism is attached to the capitalists. In this case Marx believes people in various places in the world, at various times in history organize the production of material goods (Jones, 2010, p. 78). The production of material goods encourages people to change something to have a function or value. Therefore, the modification is process of change to have value, use value and convert something to be valuable. This is confirmed by Habermas (Barker, 2004, p. 42) that the increasing commodification of the world lives by huge corporations which will change people from the figure of citizen as rational people to consumers who are not rational due to the decline of social existential questions into merely a question of chasing money.

Commodification conducted in Mount Kawi is an attempt to change things to have use-value and can be sold to the public. Capitalist productive forces have been able to create false needs. Therefore, people can unconsciously make peace with the capitalist system, and ensure the continuity (Strinati, 2010, p. 104). Through various means and supporting roles performed by a number of people and communities, they provide various facilities as form of essential needs to support the ritual. Pilgrimage rituals are actually carried out only for prayer and rituals at the tomb but now it is expanding to more complementary means. The cultural industry has formed tastes and trends of the masses so that they create awareness and desire for the false needs (Strinati, 2010, p. 107). The culture industry has affected the visitors in Mount Kawi to complete themselves before doing the rituals before praying at the tomb. This is done by the capitalist society to the culture for them to be obedient before the laws of capitalist commodity, so the cultural industry is intended only for mass production based on the mechanisms of power producers (Piliang, 2003, pp. 94-95). Society considers it important because they feel there is something not yet complete. In view of Gramsci's theory of hegemony, this expressed the view that the subordinate groups accept the idea of value, as well as the leadership of the dominant group not because they are asked physically and mentally, but for a reason that is created by the dominant group to secure the ideology implanted. Culture in Gramsci's theory is placed in the concept of common sense. Common sense is a way of understanding a person who is not critical and are often not aware of the world (Simon, 1991, p. 64). Unconscious of the world causes people to follow this existing flow.

Industrial culture is created to have an impact on the existing socio-cultural aspects. The diversity of visitors in Mount Kawi creates cultural diversity and establish interaction between one another despite ethnic differences. Increasing buildings nuances of Chinese, the Goddess Kwan Im, mosques around the tomb and the diversity of activities performed in the month of Suro and Maulud show the impact of commodification. Commodification is a process that is closely associated with capitalism, that is the object, quality, and signs become a commodity whose purpose is to be sold on the market (Barker, 2004, p. 28). Their ritual activities in Mount Kawi is inseparable with the socio-economic system. With the ritual attended by many visitors 


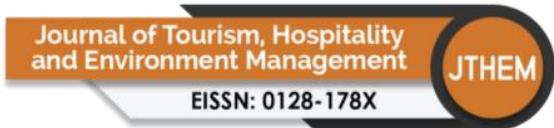

Volume 6 Issue 24 (September 2021) PP. 13-19 DOI 10/35631/JTHEM.624002

bring plenty of sustenance impact on the florists, food vendors, souvenir sellers, puppeteers, visitors, parking attendants, as well as other service seller. This can improve the local economy and increase government budget in Malang regency.

\section{Conclusion}

Mount Kawi as pesarean for Eyang Djoego and Imam Soedjono has attracted wide public attention, both ethnic Chinese and non-Chinese. Building diversity and a wide range of performing arts held in Mount Kawi give emergence of cultural industries wrapped by the idea of religious tourism. The existence of this religious tourism encourages government, private, and community to produce commodity. Cultural commodity in Mount Kawi is inseparable from the role of the ruler who applies use value and sale value to the community. Capitalist also plays in this process of commodification. Capitalism is based on prioritizing profit for their idea of materialism. Government policy towards religious tourism in the area of Mount Kawi thus is a must. People who visit the Mount Kawi are required to pay for retribution which also goes along with the idea of commodification by the capitalist. Commodification in Mount Kawi can be profitable for the three elements that play their role very well, which are Malang government, private (Ngesti Gondo Foundation), and the local community.

\section{References}

Alamanda, T.D., Kania, I., Setiawan, R. and Rahayu. S.S. (2020). Business Strategy for Religious Tourism in Mount Haruman, Indonesia, IAPA Proceedings Conference, [S.1.], p. 369-384, dec. 2020, https://doi.org/10.30589/proceedings.2020.416.

Astiyanto, Heniy. (2006). Filsafat Jawa (Menggali Butir-butir Kearifan Lokal). Yogyakarta: Warta Pustaka.

Bimantyo, H. \& Islami, N.W. (2019). Rencana Tata Kelola Pasar Wisata Gunung Kawi Desa Wonosari Kecamatan Wonosari Kabupaten Malang. Karta Rahardja E-Jurnal Inovasi dan Pembangunan Daerah, 1 (2) (2019)

Barker, C. (2004). The SAGE Dictionary of Cultural Studies. London: Sage Publication.

Choe, J. Y. and Hitchcock, M., (2018). Pilgrimage to Mount Bromo, Indonesia. In: Olsen, D.H. and Trono, A., eds. Religious Pilgrimage Routes and Trails: Sustainable Development and Management. Wallingford, Oxfordshire: CABI Publishing, 180-195.

Creswell, J. W. (2007). Qualitative Inquiry \& Research Design: Choosing Among Five Approaches (2nd ed.). London: Sage Publication.

Endraswara, S. (2003). Mistik Kejawen: Sinkretisme, Simbolisme, dan Sufisme dalam Budaya Spiritual Jawa. Yogyakarta: Narasi.

Fleischer. (2000). The Tourist behind the Pilgrim in the Holy Land. International Journal of Hospitality Management, 19 (3): 311-326

Fatimah, Siti. (2015). Strategi Pengembangan Objek Daya Tarik Wisata Religi (Studi kasus di Makam Mbah Muzakir Sayung Demak). (Bachelor's Thesis). Universitas Islam Negeri Walisongo: Semarang

Ismayanti. (2010). Pengantar Pariwisata. Jakarta: Grasindo

Jaelani, A., Setyawan, E. dan Nursyamsudin. (2017). Religi, Budaya Dan Ekonomi Kreatif: Prospek dan Pengembangan Pariwisata Halal di Cirebon. AlMustashfa: Jurnal Penelitian Hukum Ekonomi Islam, 2, (2), Desember 2017

Jigang, Bao. \& Yunmei, Chen. (1996). Development of Religious Tourism-A Case Study of Nanhua Temple in Guangdong Province. Guangzhou: CNKI

Jones, P. (2010). Pengantar Teori-Teori Sosial: dari Teori Fungsional hingga PostModernisme. Jakarta: Pustaka Obor Indonesia. 


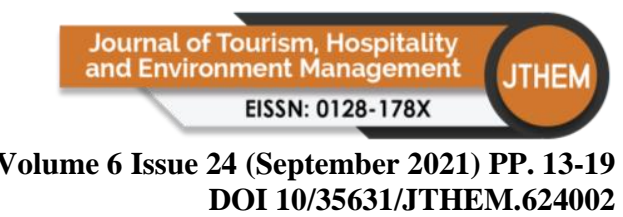

Moleong, L. J. (2014). Metode Penelitian Kualitatif. Bandung: Remaja Rosdakarya.

Piliang, A. Y. (2003). Hipersemiotika: Tafsir Cultural Studies atas Matinya Makna. Yogyakarta: Jalasutra.

Rahmania, A. (2016). Etnografi Masyarakat Gungung Kawi Kabupaten Malang. J-PIPS, 2 (2) Januari-Juni 2016, pp. 161-179

Som, AP. \& Badarneh, MB. (2011). Tourist Satisfaction and Repeat Visitation; Toward a New Comprehensive Model. International Journal of Human and Social Sciences 6:1

Smith, V. L. (1992). Introduction: The quest in guest. Annals of Tourism Research, 19, 1-17.

Siddiq, Abdullah. (2015). Atraksi Wisata Religi di Masjid Syahbuddin Kabupaten Siak Provinsi Riau. JOM FISIP, 2 (2) Oktober 2015

Soekadijo, R. G. (2000). Anatomi Pariwisata Memahami Pariwisata Sebagai Systemic Linkage. Jakarta: PT. Gramedia Pustaka Utama.

Sulistyorini, D. Sudardi, B.. Warto, \& Wijaya, M. (2018). Culture Tourism to Pesarean Kawi Mountain as A Culture of Cultural Products. Advances in Social Science, Education and Humanities Research (ASSEHR), vol. 279

Utama, I Gusti Bagus Rai. (2015). Pengembangan Wisata Kota Sebagai Pariwisata Masa Depan Indonesia. (Seminar Nasional Space \#1) "Penataan Ruang Berkearifan Lokal Dalam Pembangunan Berkelanjutan"

Widagdo, Ridwan. \& Rokhlinasari, Sri. (2017). Dampak Keberadaan Pariwisata Religi terhadap Perkembangan Ekonomi Masyarakat Cirebon. Al-Amwal , 9 (1) 